\title{
Roles of neutrophil gelatinase-associated lipocalin (NGAL) in human cancer
}

\author{
Saverio Candido ${ }^{1,2}$, Roberta Maestro ${ }^{3}$, Jerry Polesel ${ }^{2}$, Alessia Catania ${ }^{1}$, Francesca \\ Maira ${ }^{1}$, Santo S. Signorelli ${ }^{4}$, James A. McCubrey ${ }^{5}$ and Massimo Libra ${ }^{1}$ \\ ${ }^{1}$ Department of Bio-medical Sciences, Section of Pathology \& Oncology, Laboratory of Translational Oncology \& Functional \\ Genomics, University of Catania, Catania, (Italy); \\ ${ }^{2}$ Epidemiology and Statistic Unit, CRO National Cancer Institute, Aviano, (Italy); \\ ${ }^{3}$ Unit of Experimental Oncology 1, CRO National Cancer Institute, Aviano, (Italy); \\ ${ }^{4}$ Department of Medical and Pediatric Sciences, Medical Angiology Unit; University of Catania, Catania (Italy); \\ ${ }^{5}$ Brody School of Medicine at East Carolina University, Department of Microbiology \& Immunology, Greenville, NC, (USA); \\ Correspondence to: Massimo Libra, email: mlibra@unict.it
}

Key words: NGAL, LCN2, Lipocalin 2, mRNA expression, cancer, biomarker, prognostic factor, metastasis, protein expression Received: December 23, $2013 \quad$ Accepted: January 30, $2014 \quad$ Published: February 1, 2014

This is an open-access article distributed under the terms of the Creative Commons Attribution License, which permits unrestricted use, distribution, and reproduction in any medium, provided the original author and source are credited.

\section{ABSTRACT:}

Cancer remains one of the major cause of death in the Western world. Although, it has been demonstrated that new therapies can improve the outcome of cancer patients, still many patients relapse after treatment. Therefore, there is a need to identify novel factors involved in cancer development and/or progression. Recently, neutrophil gelatinase-associated lipocalin (NGAL) has been suggested as a key player in different cancer types. Its oncogenic effect may be related to the complex NGAL/ MMP-9. In the present study, NGAL was analyzed at both transcript and protein levels in different cancer types by analysing 38 public available microarray datasets and the Human Protein Atlas tool.

NGAL transcripts were significantly higher in the majority of solid tumors compared to the relative normal tissues for every dataset analyzed. Furthermore, concordance of NGAL at both mRNA and protein levels was observed for 6 cancer types including bladder, colorectal, liver, lung, ovarian, and pancreatic. All metastatic tumors showed a decrease of NGAL expression when compared to matched primary lesions.

According to these results, NGAL is a candidate marker for tumor growth in a fraction of solid tumors. Further investigations are required to elucidate the function of NGAL in tumor development and metastatic processes.

\section{INTRODUCTION}

Metastatic spreading is the major cause of death in cancer patients. Several molecules have been shown to contribute to tumor invasion and spreading. In this manuscript the roles of neutrophil gelatinase-associated lipocalin (NGAL) in cancer development and progression are described.

Members of the lipocalin protein family are characterized by their ability to bind small hydrophobic molecules (such as prostaglandins, retinoids, arachidonic acid, hormones and fatty acids). They often bind to specific cell-surface receptors and form macromolecular complexes. Highly conserved lipocalin crystal structures consist of a single eight-stranded continuously hydrogenbonded antiparallel $\beta$-barrel delineating a calyx shape, which represents the internal ligand-binding site (Figure 1). Members of the lipocalin family, in the past classified exclusively as transport proteins, have now been described to carry out a variety of different functions. Some of these functions include: retinol transport, cryptic coloration, olfaction, pheromone transport, and the enzymatic synthesis of prostaglandins, moreover the lipocalins are also involved in the regulation of the immunoresponse and 
the mediation of cell homoeostasis [1].

NGAL, also called lipocalin 2 siderocalin and $24 \mathrm{p} 3$, was identified in several forms: a monomer (25$\mathrm{kDa})$, a disulfide-linked homodimer (46-kDa), and a disulfide-linked heterodimer with human neutrophil gelatinase B (135-kDa) [2]. NGAL has several functions. In early studies NGAL was described as a factor of innate immune system. NGAL is released by neutrophils at sites of infection and inflammation to sequester bacterial ferric siderophores, participating in the antibacterial iron-depletion strategy of innate immune system [3]. Subsequently, it was shown that NGAL is responsible for iron delivery to the cytoplasm where it is accumulated and activates or represses iron-responsive genes. Iron unloading depends on the cycling of NGAL through acidic endosomes [4]. In contrast, Devireddy LR et al have shown that NGAL is also involved in apoptosis-dependent deprivation of trophic factors. Apo-NGAL, after binding to its putative receptor, $24 \mathrm{p} 3 \mathrm{R}$, is internalized and associates with an intracellular siderophore, transferring chelated iron to the extracellular medium, thereby reducing intracellular iron concentration which leads to the expression of the pro-apoptotic protein Bim, leading to the induction of apoptosis [5].

NGAL was originally identified as a protein covalently associated with $92-\mathrm{kDa}$ gelatinase/MMP9 from human activated neutrophils [2]. NGAL is expressed in many other types of cells in response to various injuries, especially in kidney diseases. Serum NGAL levels correlate clearly with the severity of renal injury, reflecting the degree of tissue damage. For this reason, NGAL may become one of the most promising next-generation biomarkers in clinical nephrology and as well as other diseases and pathological states [6].

NGAL is up-regulated by IL-1 beta, but not by TNFalpha, in type II pneumocyte-derived cell line through the induction of the NF-kB pathway [7]. IL-1 beta selectivity in inducing NGAL is due to the synthesis of IkB-zeta, a NF-kB-binding cofactor, elicited specifically by IL-1beta stimulation which is required for transcriptional activation of NGAL [8]. Stimulation with TNF-alpha in the presence of IL-17, which stabilizes the IkB-zeta transcript, is able to induce NGAL expression by IkB-zeta protein binding to NF-kB on the NGAL promoter [9]. It has been also demonstrated that activation of the NF-kB pathway is associated with up-regulation of NGAL-ErbB2-mediated signaling [10] (Figure 2).

NGAL's ability to combine in a dimeric complex with MMP-9, results in a protective action of MMP-9 from its auto-degradation and consequently results in a higher gelatinolytic action of MMP-9 on extracellular matrix [11]. By this function, it has been shown that NGAL may promote cancer development in a variety of different cancer types [12-15] (Figure 2). Conversely, anticancer activities of NGAL have been demonstrated by its ability to inhibit the pro-neoplastic factor HIF-1a, the synthesis of
HIF-1a-dependent VEGF [16,17], and phosphorylation of FAK kinase [17], as shown in colon [18], ovarian [19] and pancreatic [17] cancers.

Further evidences indicate that NGAL plays key roles in the inflammation and in the regulation of cell growth and adhesion in both normal and tumor tissues [20-23].

In the present study, NGAL transcript levels and its potential clinical implications in different cancer types were examined by bioinformatic approaches. NGAL transcript levels were explored in different cancer types by analysing public available microarray datasets. Further evaluation of NGAL protein expression were performed by analyzing the Human Protein Atlas. According to both the results of the present analyses and previous published data, NGAL potential clinical implications are also discussed.

\section{RESULTS}

\section{mRNA expression of NGAL in different tumor types}

Gene expression patterns of NGAL mRNAs present in different tumor types were obtained from several datasets (Table 1). Significant differences between tumor tissues and relative normal counterparts for each cancer type are reported in Table 1. This analysis showed that NGAL transcript levels were significantly higher in the majority of solid tumors compared to the relative normal tissues for every dataset analyzed. While, lower levels of NGAL were observed in each dataset of cervical
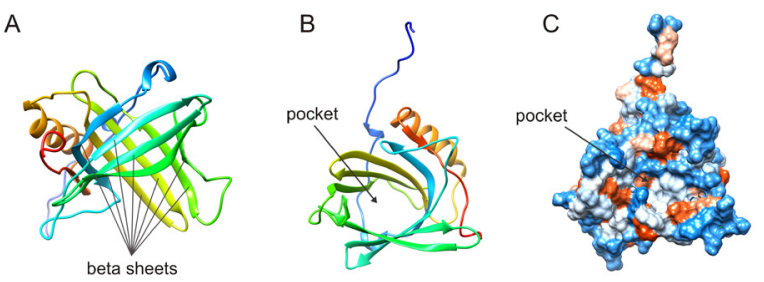

Figure 1: Highly conserved lipocalin crystal structures consist of a single eight-stranded continuously hydrogen-bonded antiparallel $\beta$-barrel (A) delineating a calyx shape, which represents the internal ligandbinding site (B). Hydrophobicity surface (C). Images were created from the RCSB PDB database (http://www.rcsb.org) (ID: 1NGL) using the UCSF Chimera package UFCS Chimera package that is developed by the Resource for Biocomputing, Visualization, and Informatics at the University of California, San Francisco (supported by NIGMS P41-GM103311). Ref: The solution structure and dynamics of human neutrophil gelatinaseassociated lipocalin by Coles M, et al. J Mol Biol. 1999; 289: $139-57$. 
Table 1: Gene expression patterns of NGAL in different cancer types from 29 datasets

\begin{tabular}{|c|c|c|c|c|c|c|c|}
\hline \multirow{2}{*}{ Cancer Type } & \multicolumn{2}{|c|}{ \# of samples } & \multirow{2}{*}{$\begin{array}{l}\text { Fold Change } \\
(\leq-2) \text { or }(\geq 2)\end{array}$} & \multirow{2}{*}{$\begin{array}{l}\mathrm{p}<0.01 \\
\text { (T-test) }\end{array}$} & \multicolumn{3}{|l|}{ Dataset } \\
\hline & Cancer & Normal & & & Author [Ref.] & Year & Platform \\
\hline \multicolumn{8}{|l|}{ Solid tumor } \\
\hline Bladder & 109 & 48 & 4.13 & $2.75 \mathrm{E}-05$ & Sanchez-Carbayo M [86] & 2006 & U133A \\
\hline Cervix & $32^{\mathrm{a}}$ & 24 & -3.21 & $4.06 \mathrm{E}-04$ & Scotto L [87] & 2008 & U133A \\
\hline \multirow{3}{*}{ Colon } & 95 & 5 & 2.62 & $1.23 \mathrm{E}-02$ & Kaiser S [88] & 2007 & \begin{tabular}{|l|} 
U133 Plus 2.0 \\
\end{tabular} \\
\hline & 81 & 24 & 4.15 & 7.04E-08 & Skrzypczak M [89] & 2010 & U133 Plus 2.0 \\
\hline & 70 & 12 & 4.78 & $7.06 \mathrm{E}-06$ & Hong Y [90] & 2010 & \begin{tabular}{|l} 
U133 Plus 2.0 \\
\end{tabular} \\
\hline \multirow{2}{*}{ Esophagus } & $17^{\mathrm{b}}$ & 17 & -5.41 & 9.27E-05 & $\mathrm{Hu}$ N [91] & 2010 & U133A \\
\hline & $53^{b}$ & 53 & -2.92 & $1.05 \mathrm{E}-06$ & Su H [92] & 2011 & U133A/B \\
\hline \multirow{2}{*}{ Head and Neck } & $6^{\mathrm{d}}$ & 4 & -18.58 & $7.33 \mathrm{E}-03$ & Schlingemann J [93] & 2005 & \begin{tabular}{|l|} 
U133A \\
\end{tabular} \\
\hline & $31^{\mathrm{c}}$ & 10 & -12.44 & 3.60E-09 & Sengupta S [94] & 2006 & \begin{tabular}{|l} 
U133 Plus 2.0 \\
\end{tabular} \\
\hline kidney & $51^{\mathrm{e}}$ & 5 & 4.15 & $4.98 \mathrm{E}-05$ & Yusenko MV [95] & 2009 & U133 Plus 2.0 \\
\hline \multirow{3}{*}{ Liver } & 35 & 10 & 8.66 & $2.32 \mathrm{E}-05$ & Wurmbach E [96] & 2007 & U133 Plus 2.0 \\
\hline & 22 & 21 & 3.48 & $5.14 \mathrm{E}-04$ & Roessler S (1) [97] & 2010 & \begin{tabular}{|l|} 
U133 Plus 2.0 \\
\end{tabular} \\
\hline & 225 & 220 & 2.94 & $6.86 \mathrm{E}-22$ & Roessler S (2) [97] & 2010 & HT U133A \\
\hline \multirow[t]{3}{*}{ Lung } & $30^{\mathrm{f}}$ & 30 & 2.79 & $1.72 \mathrm{E}-03$ & $\mathrm{Su} \mathrm{LJ}[98]$ & 2007 & U133A \\
\hline & $58^{\mathrm{f}}$ & 49 & 2.28 & $2.64 \mathrm{E}-06$ & Landi MT [99] & 2008 & U133A \\
\hline & $226^{\mathrm{f}}$ & 20 & 3.707 & $1.53 \mathrm{E}-7$ & Okayama H [100] & 2012 & \begin{tabular}{|l} 
U133 Plus 2.0 \\
\end{tabular} \\
\hline \multirow{2}{*}{ Ovary } & $185^{\mathrm{g}}$ & 10 & 5.84 & $1.54 \mathrm{E}-06$ & Bonome T [101] & 2008 & \begin{tabular}{|l|} 
U133A \\
\end{tabular} \\
\hline & $99^{\mathrm{g}}$ & 4 & 3.03 & $6.98 \mathrm{E}-04$ & Hendrix ND [102] & 2006 & U133A \\
\hline \multirow{3}{*}{ Pancreas } & $36^{\mathrm{h}}$ & 16 & 14.05 & $5.15 \mathrm{E}-06$ & Pei H [103] & 2009 & \begin{tabular}{|l|} 
U133 Plus 2.0 \\
\end{tabular} \\
\hline & $11^{\mathrm{h}}$ & 6 & 10.00 & 9.03E-05 & Segara D [104] & 2005 & U133A \\
\hline & $39^{i}$ & 39 & 7.70 & $1.64 \mathrm{E}-10$ & Badea L [105] & 2008 & U133 Plus 2.0 \\
\hline \multirow{3}{*}{ Thyroid } & $9^{j}$ & 9 & 3.77 & $9.76 \mathrm{E}-4$ & He H [106] & 2005 & U133 Plus 2.0 \\
\hline & $14^{\mathrm{i}}$ & 4 & 2.33 & 0.001 & Vasko V [107] & 2007 & U133 Plus 2.0 \\
\hline & $26^{\mathrm{j}}$ & 4 & 2.05 & $9.34 \mathrm{E}-7$ & Giordano TJ [108] & 2006 & U133A \\
\hline \multicolumn{8}{|c|}{ Hematologic tumor } \\
\hline ALL & 750 & 74 & -11.77 & $7.57 \mathrm{E}-152$ & Haferlach T [109] & 2010 & U133 Plus 2.0 \\
\hline \multirow[t]{2}{*}{ AML } & 542 & 74 & -16.94 & $2.32 \mathrm{E}-165$ & Haferlach T [109] & 2010 & U133 Plus 2.0 \\
\hline & 285 & 8 & -4.91 & $5.00 \mathrm{E}-03$ & Valk PJ [110] & 2004 & U133A \\
\hline CLL & 448 & 74 & -42.98 & $7.73 \mathrm{E}-194$ & Haferlach T [109] & 2010 & U133 Plus 2.0 \\
\hline Myeloma & $9^{\mathrm{k}}$ & 5 & -3.90 & 0.002 & Agnelli L [111] & 2009 & U133A \\
\hline
\end{tabular}

Legend: Solid tumor: Cervix: ${ }^{a}$ Cervical Squamous Cell Carcinoma. Esophagus: ${ }^{b}$ Esophageal Scquamous Cell Carcinoma; Head and Neck: ${ }^{\mathrm{C} N a s o p h a r y n g e a l ~ C a r c i n o m a ; ~}{ }^{\mathrm{d} S q u a m o u s}$ Cell Carcinoma. Kidney: ${ }^{\mathrm{R}}$ Renal Carcinoma; Liver: (1), dataset 1; (2) dataset 2; Lung: ${ }^{\mathrm{f}}$ Lung adenocarcinoma; Ovary: ${ }^{\mathrm{g} O v a r i a n}$ Carcinoma; Pancreas: ${ }^{\mathrm{P}}$ Pancreatic Carcinoma; ${ }^{\mathrm{i}}$ Pancreatic Ductal Adenocarcinoma; Thyroid: ${ }^{\mathrm{T}}$ Thyroid Gland Papillary Carcinoma

Hematologic tumor: ALL, Acute Lymphoblastic Leukemia; AML, Acute Myeloid Leukemia; CLL, Chronic Lymphocytic Leukemia. Myeloma: kPlasma Cell Leukemia. 
Table 2: NGAL transcripts in metastatic tissues compared to the relative primary tumor

\begin{tabular}{|c|c|c|c|c|c|c|c|}
\hline \multirow{2}{*}{ Cancer Type } & \multicolumn{2}{|c|}{ \# of samples } & \multirow{2}{*}{$\begin{array}{l}\mathrm{FC}(\leq-1.5) \text { or } \\
\geq 1.5)\end{array}$} & \multirow{2}{*}{$\mathrm{p}<0,05$ (T-test) } & \multicolumn{3}{|l|}{ Data set } \\
\hline & metastasis & primary & & & Author [Ref.] & Year & Platform \\
\hline \multirow[t]{2}{*}{ Colorectal } & 43 & 330 & -3.191 & $1.56 \mathrm{E}-06$ & Bittner M[a] & 2005 & U133 Plus 2.0 \\
\hline & 27 & 56 & -5.437 & $1.04 \mathrm{E}-06$ & Tsuji S [112] & 2012 & U133 Plus 2.0 \\
\hline Kidney & 60 & 9 & -1.960 & $4.00 \mathrm{E}-03$ & Jones J [113] & 2005 & U133A \\
\hline \multirow{2}{*}{ Melanoma } & 40 & 16 & -2.475 & $3.00 \mathrm{E}-03$ & Riker AI [114] & 2007 & U133 Plus 2.0 \\
\hline & 52 & 31 & -4.849 & $1.12 \mathrm{E}-08$ & $\mathrm{Xu} \mathrm{L} \mathrm{[115]}$ & 2008 & U133A \\
\hline \multirow{2}{*}{ Ovarian } & 75 & 166 & -1.999 & $2.00 \mathrm{E}-03$ & Bittner M[a] & 2005 & U133 Plus 2.0 \\
\hline & 16 & 74 & -1.537 & $4.30 \mathrm{E}-03$ & Anglesio MS [116] & 2008 & U133 Plus 2.0 \\
\hline \multirow[t]{2}{*}{ Prostate } & 5 & 27 & -1.578 & $2.60 \mathrm{E}-02$ & Vanaja DK [117] & 2003 & U133A/B \\
\hline & 6 & 7 & -5.735 & $7.76 \mathrm{E}-04$ & Varambally S [118] & 2005 & U133 Plus 2.0 \\
\hline
\end{tabular}

[a] GEO Series GSE2109; FC, Fold change

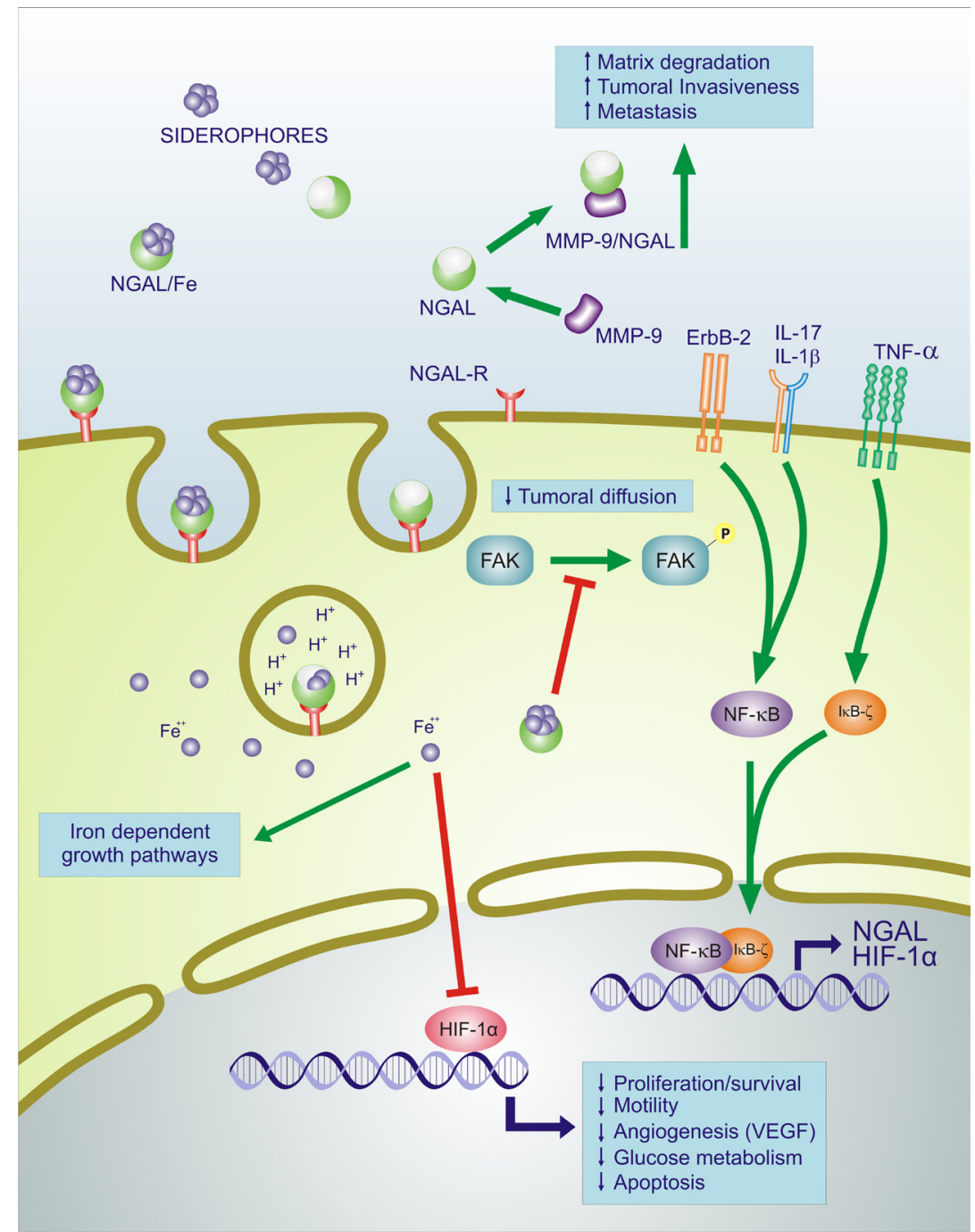

Figure 2: Effects of NGAL on survival, motility, angiogenic, apoptotic and glucose metabolism. NGAL: neutrophil gelatinase-associated lipocalin; MMP9: matrix metalloproteinase 9; NGAL-R: NGAL receptor; ErbB-2: v-Erb-B2 Avian Erythroblastic Leukemia Viral Oncogene Homolog = HER2; TNF- $\alpha$ : Tumor Necrosis Factor Alpha; IL-17: interleukin-17; IL-1 $\beta$ : interleukin-1 beta; FAK:

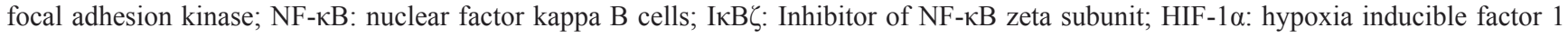
alpha; VEGF: vascular endothelial growth factor. Fe++: Ferrous iron; Green lines with arrows indicate activation of pathway, red lines with blocked ends indicate inhibition of pathway, blue lines indicate transcriptional activation and additional events. 
cancer, esophageal cancer, head and neck cancer and in haematological malignancies. In Table 2 are presented the significant differences of NGAL transcript levels observed in metastatic tissues compared to those of the relative primary tumor. The results showed that in all dataset analyzed the levels were significantly lower in the metastatic tissues than in primary tumors from 5 different tumor types, including colorectal, kidney, melanoma, ovarian and prostate (Table 2).

In Figure 3 the distribution of NGAL transcript levels among cancer cases and normal samples is shown. The percentage of tumor cases showing NGAL transcript levels below the $25^{\text {th }}$ percentile and above the $75^{\text {th }}$ percentile of the "normal" samples is also reported.

\section{Protein expression of NGAL in different tumor types}

To understand if there was an association between mRNA and protein NGAL expression, an immunohistochemistry evaluation was performed by analysis of Human Protein Atlas web site. In Figure 4 immunohistochemistry analysis of NGAL in 15 solid cancer types are shown. Cancer types with negative immunostaining are not shown. The data demonstrated
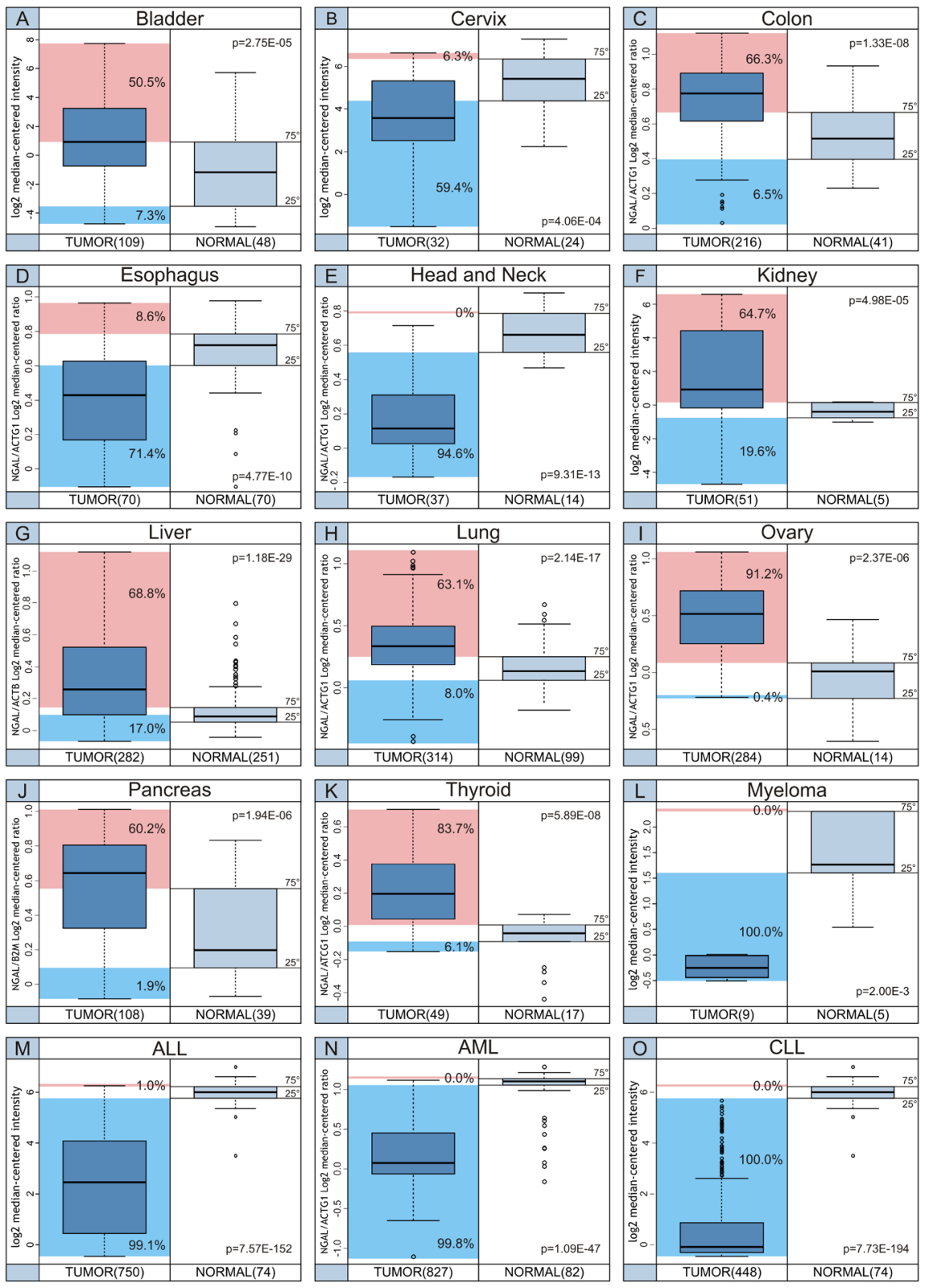

Figure 3: Distribution of NGAL transcript levels among cancer cases and normal samples. The percentage of tumor cases, indicated for each tumor setting, shows NGAL transcript levels below the $25^{\text {th }}$ percentile (Cyan box) and above the $75^{\text {th }}$ percentile (Magenta box) of the "normal" samples. 
that concordance of NGAL at both mRNA and protein levels was obtained for the following cancer types: bladder, colorectal, liver, lung, ovarian, and pancreatic (Table 1 and Figure 4, Panels: A, E, I, J, H and L). Cervical, esophageal/stomach and head and neck cancers showed a moderate positive immunostaining (Figure 4, panel D, F and G), while mRNA expression levels were lower in cancer tissue compared to the normal counterpart (Table, 1).

Conversely, weak immunostaining $(<10 \%$ of cases) or negative protein expression levels were observed in brain, breast, melanoma and prostate cancers. Accordingly, no significant differences in NGAL mRNA expression were observed between cancer and relative normal counterpart in all datasets analysed for each of these 4 cancer types (brain, breast, melanoma and prostate) (Figure 4, Panel B, C, K and M).

Although, higher mRNA levels were detected in renal and thyroid cancers than in relative normal counterparts (Table 1), a negative immunostaining was
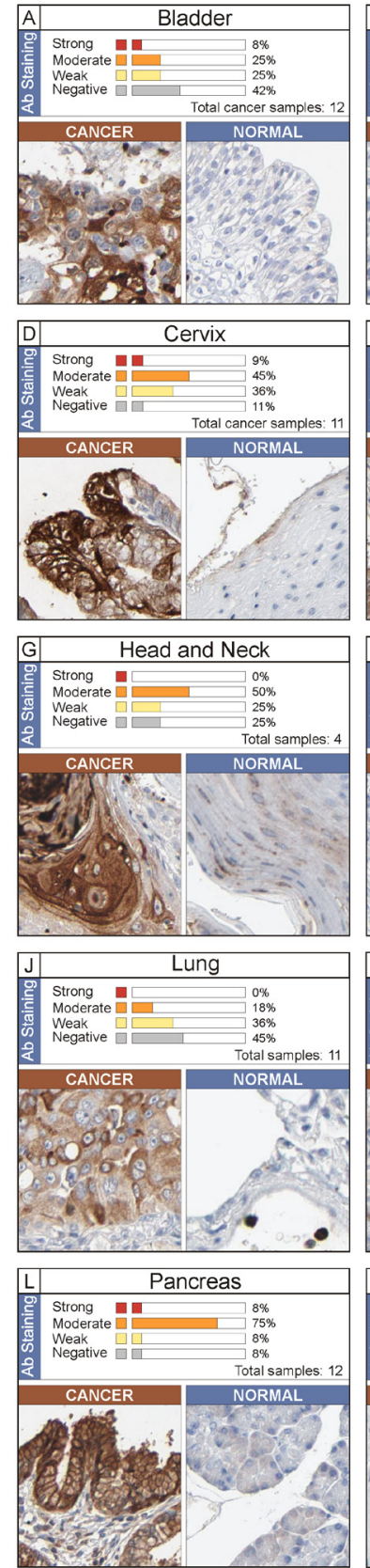
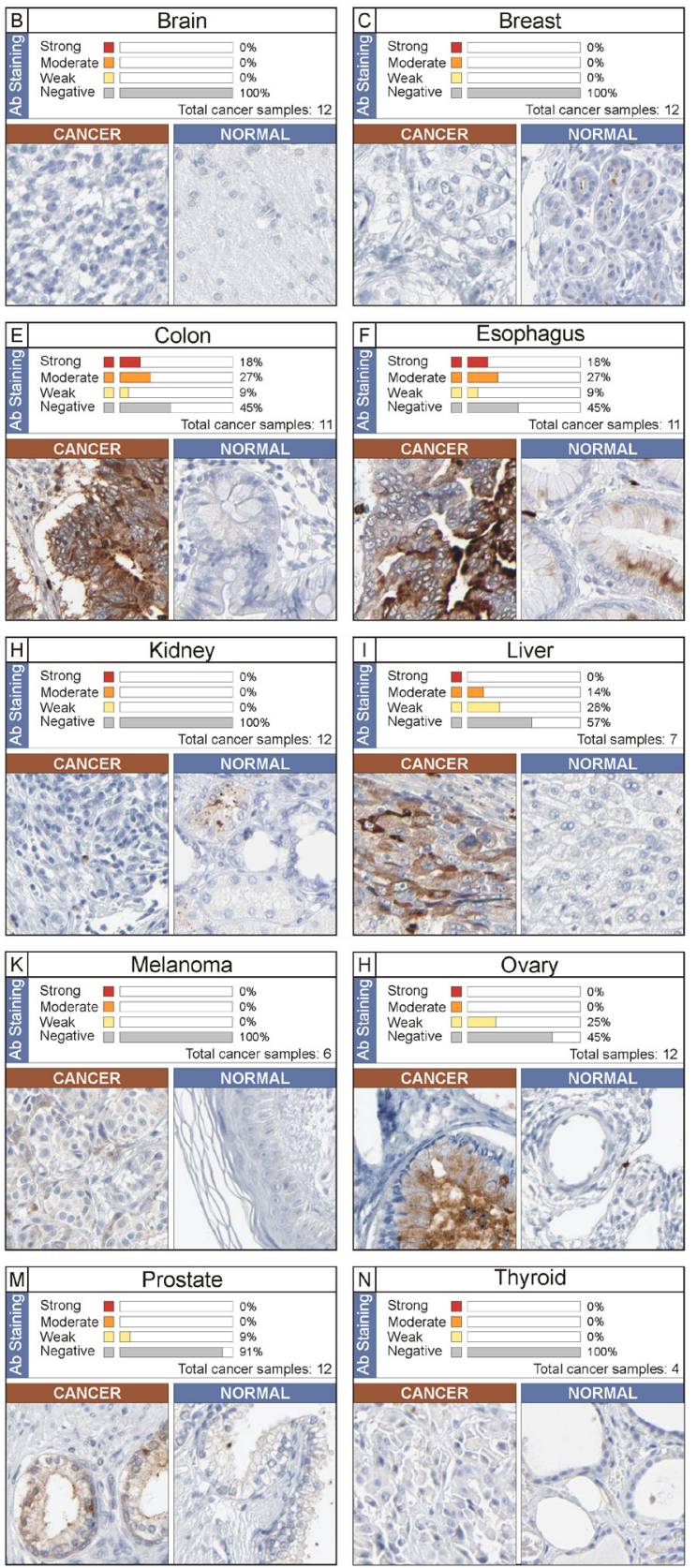

Figure 4: Immunohistochemistry analysis of NGAL expression in human cancer. The data were obtained from the Human Protein Atlas. A single representative case for each cancer type (total 15) is shown along with its normal counterpart. Expression of NGAL in cancer sample was evaluated as strong, moderate, weak and negative immunostaining. The percentage is referred to the total cancer samples analyzed for each tumor type. 
Table 3: Clinical impact of NGAL expression pattern in different cancer type according to previous studies

\begin{tabular}{|c|c|c|c|}
\hline TUMOR TYPE & METHODS & CLINICAL IMPACT OF NGAL EXPRESSION & AUTHOR [REF.] \\
\hline \multicolumn{4}{|l|}{ SOLID TUMORS } \\
\hline \multirow{2}{*}{ BLADDER } & $\mathrm{CM}, \mathrm{GZ}, \mathrm{MS}$ & Diagnostic marker & $\begin{array}{l}\text { Roy R [24] } \\
\text { Monier F [25] }\end{array}$ \\
\hline & $\begin{array}{l}\text { GZ, } \\
\text { ELISA }\end{array}$ & Early marker of tumor progression & Monier F [26] \\
\hline \multirow{3}{*}{ BRAIN } & $\begin{array}{l}\text { IHC, } \quad \text { GZ, } \\
\text { ELISA }\end{array}$ & Diagnostic marker & Smith $[15]$ \\
\hline & $\mathrm{IHC}$ & $\begin{array}{l}\text { Positive correlation with high proliferation index in } \\
\text { primary tumor }\end{array}$ & Barresi [28] \\
\hline & $\mathrm{IHC}$ & Associated with poor outcome & Liu MF [27] \\
\hline \multirow{6}{*}{ BREAST } & IHC & Associated with poor outcome & Stoesz SP [29] \\
\hline & ELISA & Positive correlation with lymphatic node metastasis & Shen ZZ [31] \\
\hline & ELISA & Positive correlation with breast cancer aggressiveness & $\begin{array}{l}\text { Provatopoulou } \\
{[32]}\end{array}$ \\
\hline & $\mathrm{IHC}$ & $\begin{array}{l}\text { Positive correlation with poor prognosis in primary } \\
\text { human breast cancer }\end{array}$ & Bauer M [30] \\
\hline & IHC & Positive correlation with poor outcome & $\operatorname{Li}[10]$ \\
\hline & IHC & Positive correlation with poor outcome & Wenners [38] \\
\hline CERVICAL & $\mathrm{IHC}$ & Positive correlation with HPV type & Syrjänen [39] \\
\hline \multirow{5}{*}{ COLORECTAL } & IHC, FISH & Positive correlation with tumor trasformation & Nielsen [40] \\
\hline & ELISA & Prognostic utility in metastatic patients & Martì $[44,45]$ \\
\hline & PCR, GZ & Diagnostic marker & Catalan [43] \\
\hline & ELISA & Not suitable as a diagnostic marker & Fung KY [46] \\
\hline & ELISA & Not useful marker of progression & McLean MH [47] \\
\hline \multirow{2}{*}{ ESOPHAGEAL } & GZ, IHC, WB & Positive correlation to cancer differentiation & Zhang [14] \\
\hline & $\mathrm{IHC}$ & Positive correlation with progression & Du ZP [49] \\
\hline \multirow[t]{2}{*}{ GASTRIC } & $\begin{array}{l}\text { IHC, ELISA, } \\
\text { WB }\end{array}$ & Positive correlation with poor outcome & Kubben [13] \\
\hline & IHC, ELISA & $\begin{array}{l}\text { Diagnostic marker and positive correlation with poor } \\
\text { outcome }\end{array}$ & Wang HJ [60] \\
\hline HEAD \& NECK & ELISA & Positive correlation with poor outcome & Lin CW [61] \\
\hline $\mathrm{HCC}$ & $\mathrm{IHC}$ & Positive correlation with poor outcome & Zhang Y [62] \\
\hline LUNG & $\mathrm{IHC}$ & Positive correlation with poor outcome & Friedl A [20] \\
\hline PANCREATIC & ELISA & Diagnostic marker & Moniaux N [71] \\
\hline \multirow{2}{*}{ OVARIAN } & $\begin{array}{l}\text { IHC, ELISA, } \\
\text { WB }\end{array}$ & Promotion of epithelial to mesenchymal transition & Lim R [19] \\
\hline & $\begin{array}{l}\text { PCR, IHC, } \\
\text { ELISA }\end{array}$ & Positive correlation to cancer differentiation & Cho $[65]$ \\
\hline \multirow{2}{*}{ RENAL } & $\mathrm{IHC}$ & Positive correlation with malignant phenotype & Barresi [76] \\
\hline & ELISA & Positive correlation with poor outcome & Porta [77] \\
\hline \multirow[t]{2}{*}{ THYROID } & IHC, Real time & Positive correlation with malignant phenotype & Iannetti [81] \\
\hline & $\mathrm{IHC}$ & Diagnostic marker & Barresi $[79,80]$ \\
\hline \multicolumn{4}{|l|}{$\begin{array}{l}\text { HEMATOLOGICAL } \\
\text { MALIGNANCIES }\end{array}$} \\
\hline AML & RT-PCR & Positive correlation with better prognosis & Yang WC [82] \\
\hline CML & RT-PCR & $\begin{array}{l}\text { Positive correlation with early stage of disease and } \\
\text { BCR-ABL positivity }\end{array}$ & Villalva C [84] \\
\hline
\end{tabular}

AML, Acute Myeloid Leukemia, CM, Chromatography; CML, Chronic Myelogenous Leukemia; GZ, Gel zymography; HCC, Hepatocellular Carcinoma; IHC, Immunohistochemistry. MS, Mass Spectrometry. 
observed (Figure 4, Panel H and N). Finally, concordant negative mRNA and protein levels of NGAL were observed in the majority of haematological malignancies (data not shown).

\section{Clinical impact of different NGAL expression pattern}

To further understand if different NGAL expression pattern may affect the clinical behaviour of several cancer types, an analysis of previously published studies was performed and is summarized in Table 3.

\section{DISCUSSION}

Until now, NGAL has been investigated primarily as an inflammatory factor and as a marker of kidney damage [6]. However, recent studies have indicated that NGAL has potential roles in cancer development and NGAL may have pro-oncogenic or anti-oncogenic functions [22]. In fact, its oncogenic effect is related to the complex NGAL/ MMP-9 [11]; while its anti-tumor effect is related to the inhibition of the pro-neoplastic factor HIF-1a, the HIF1a-dependent VEGF and FAK $[16,17]$. In the present study, computational and IHC evaluations were performed to understand whether differences in NGAL transcript or protein levels occur in different cancer types when compared with the relative normal tissues or the metastatic counterparts. The results obtained for each tumor type are discussed below in relation to previously published studies.

\section{Solid Tumors}

\section{Bladder}

The current study reveals that both mRNA transcript and protein levels were higher in bladder cancer tissues than in the normal counterparts. Accordingly, 50.5\% of cases displayed NGAL transcripts above the $75^{\text {th }}$ percentile of the "normal" values suggesting its role as a diagnostic marker. These data are in agreement with previous investigations in which NGAL along with MMP-9 were overexpressed in urothelial bladder carcinomas suggesting their role as early diagnostic markers for this tumor type $[24,25]$. Reduced protein levels of both NGAL and MMP9 have been detected in urine samples from bladder cancer patients with clinical relapse suggesting that reduced levels of these proteins may be used as indicators of tumor progression [26].

\section{Brain}

A significant association of MMPs and NGAL expression was detected in urine from brain cancer patients and in tumor specimens. Additionally, surgical resection of the tumor resulted in a reduction of both MMPs and NGAL in urine samples [15]. The identification of new potential molecular targets in this cancer type may be very helpful to discover new therapeutic strategies. Immunohistochemistry analysis reveals that NGAL expression is frequently up-regulated in gliomas and is associated with poor clinical outcome [27]. Barresi et al show that NGAL was overexpressed in primary high grade brain tumors and not in the metastatic cases [28]. According to the exclusion criteria designed for the purpose of our present study, no data on brain cancer were generated by computational analysis. Accordingly, NGAL protein expression was not detected through the Human Protein Atlas evaluation.

\section{Breast}

Similar observations acquired for brain tumors were obtained for breast cancer as no data were generated by our computational analysis. The expression pattern of NGAL has been evaluated by several authors and generated conflicting results on the clinical significance of this protein in breast cancer.

A heterogeneous pattern of expression at the mRNA and protein levels was observed in breast cancer patients in a study conducted by Stoesz SP et al [29]. The authors also described a significant correlation between NGAL expression and other markers of poor prognosis, including estrogen and progesterone receptor-negative status and high proliferation (S-phase fraction) [29]. These studies were also confirmed by Bauer M et al [30]. Similarly, Shen ZZ et al showed that MMP-9 and MMP-9/NGAL complex expression were higher in breast cancer than in benign breast and/or normal tissues [31]. While, in the study conducted by Provatopoulou X et al. in a large series of breast cancer patients, MMP-9 and NGAL were overexpressed in cancer and this overexpression was associated with the severity of disease but no significant correlation was found for the complex formation [32].

In a transgenic mouse model of breast cancer, Berger et al. demonstrated that lack of NGAL in mice leads to a reduction of tumor growth. This reduction was attributed to an NGAL-dependent decrease of MMP-9 activity and to a lack of high molecular weight MMP activity [33]. Accordingly, Li et al have shown that NGAL expression is associated with increased metastasis and poor prognosis in breast cancer patients [10]. The results obtained by Leng et al in an animal model of breast cancer suggest that the suppression of NGAL function, by an inhibitory monoclonal antibody, has a great potential for breast 
cancer therapy, particularly by interfering with metastasis in aggressive types of breast cancer [34]. Conversely, in a previous study it was shown that NGAL overexpression promotes in vivo the development of lung metastasis. [35]. Our recent studies indicate that increased NGAL expression did not alter the sensitivity of the MCF-7 breast cancer cell line to the chemotherapeutic drug doxorubicin [36]. However, ectopic NGAL expression did alter the sensitivity of breast cancer cells to targeted therapy [37]. Furthermore, NGAL was found to be a predictive marker for complete response after neo-adjiuvant chemotherapy in low-risk subgroups of breast cancer patients and may be considered as an independent prognostic factor for decreased disease free survival in primary human breast cancer [38].

\section{Cervical cancer}

A recent analysis conducted by immunohistochemistry on a set of cervical biopsy specimens from 225 women showed a close relationship between NGAL expression levels, HPV lesion grade and detection of high risk HPV types. Up-regulation of NGAL in higher grade lesions is likely to from the suppression of wild-type p53 by the HPV E6 oncoprotein. Suppression of p53 results in elimination of p53 block of NGAL transcription [39]. These data were in agreement with our IHC evaluation but not in line with our computational analysis as only $6.3 \%$ of cervical cases displayed NGAL transcripts above the $75^{\text {th }}$ percentile of "normal" values, while $59.4 \%$ below the $25^{\text {th }}$ percentile.

\section{Colorectal cancer}

In 1996 Nielsen et al analysed the role of NGAL by both immunohistochemistry and mRNA by in situ hybridization in colon cancer and in inflammatory colorectal diseases. Increased expression of NGAL was detected both in non-malignant epithelium such as diverticulitis, inflammatory bowel disease and in malignant colonic lesions. In adenocarcinomas, NGAL overexpression was observed in the transitional mucosa and in the superficial ulcerated area. On the other hand, NGAL expression was not detected in lymph node metastases from this adenocarcinoma [40]. The authors speculate that NGAL is predominantly involved in inflammatory reaction and in tumor transformation, while it does not appear to play a prominent role in metastatic process.

However, Lee et al have shown that NGAL may function as a metastasis suppressor in colon cancer cells. In their studies, they genetically manipulated highly metastatic human colon cancer cell lines, which normally express low NGAL protein levels, to overexpress NGAL. Ectopic expression of NGAL suppressed, in vivo, the liver metastasis of metastatic human colon cancer cell lines in experimentally-driven metastasis assays [18]. $\mathrm{Hu}$ et al examined the potential molecular mechanism of NGAL involvement in colorectal cancer. They demonstrated that NGAL overexpression altered the subcellular localization of E-cadherin and catenins, decreased E-cadherinmediated cell to cell adhesion, enhanced cell-matrix attachment, and increased cell motility and in vitro invasion. They proposed that NGAL exerted these effects through the alteration of the subcellular localization of Rac1, one of Rho small GTPases, in an extracellular matrix-dependent manner, but not by MMP-9 [41]. Recently, Bousserouel S et al have shown, in a preclinical model of colon carcinogenesis, that NGAL is significantly upregulated only in advanced stages of tumor progression [42].

Real time PCR and zymographic analysis on visceral adipose tissue (VAT) biopsies from 11 colon cancer patients revealed increased levels of NGAL and other inflammation associated factors like osteopontin, tumor necrosis factor- $\alpha$ (TNF- $\alpha)$, and chitinase-3 like- 1 compared to control subjects, suggesting their involvement in cancer development and progression [43].

Recently, Martí J et al showed the prognostic utility of NGAL mainly in metastatic CRC [44, 45]. Higher levels in colon cancer cases then controls were observed by Fung KY et al but the authors concluded that it was not a promising biomarker for the diagnosis of $\mathrm{CRC}$ as the sensitivity of NGAL was found to be $24 \%$ at $90 \%$ specificity [46]. Accordingly, although NGAL is still expressed by the majority of human neoplastic colorectal lesions, the author it is not a useful biomarker for determining disease progression from adenomatous to malignant colorectal neoplasia [47]. Our analysis, in line with the majority of previous studies, shows the upregulation of NGAL in adenocarcinoma tumor samples and reduced expression in metastatic samples.

\section{Esophageal cancer}

Esophageal cancer is the eighth most common incident cancer in the world and ranks sixth among all cancers in mortality. Esophageal cancers are classified into two histological types; esophageal squamous cell carcinoma (ESCC), and adenocarcinoma, and the incidences of these types show a striking variety of geographic distribution, possibly reflecting differences in exposure to specific environmental factors. Both alcohol consumption and cigarette smoking are major risk factors for the development of ESCC [48].

Zhang et al performed immunohistochemistry, western blot and gelatin zymography on 81 paraffin sections including ESCC, normal mucosa, simple hyperplasia and dysplasia, and on 73 fresh specimens of ESCC to evaluate the role of NGAL in ESCC. Immunohistochemical studies revealed that ESCC have a 
diverse and obvious whole-cytoplasmic staining pattern for NGAL, while normal oesophageal epithelium presented a weak positive signal within a restricted cytoplasmic area. On western blot analysis, NGAL expression level was found to be significantly higher in ESCC than in normal mucosa, and positively correlated with cancer cell differentiation. No significant association was observed between NGAL expression and cell proliferation. Finally, the authors showed higher enzymatic activity of NGAL/ MMP-9 complex in ESCC than in normal mucosa. These findings suggest that NGAL is involved in differentiation pathways and invasive progression of ESCC [14]. Similar data were reached by $\mathrm{Du}$ et al, [49]. Accordingly our IHC evaluations show that NGAL is overexpressed in tumor and not in normal tissue. However, different trend is observed by analyzing the transcript levels as $71.4 \%$ of cases displayed NGAL transcripts below the 25 th percentile of "normal" values, while $8.6 \%$ above the 75 th percentile.

Fang et al. identified a new NGALR isoform designated as NGALR-3, that results from alternative splicing. Interestingly, it was shown that the NGALR-3 isoform was overexpressed in $70 \%$ of esophageal carcinoma cases in comparison with those of normal adjacent epithelium. These findings suggest that the new NGALR-3 variant could play a more important role in esophageal carcinoma. The authors proposed that the novel NGALR-3 isoform could mediate a unilateral intracellular iron-delivery pathway which increased intracellular iron levels. This could be involved in the tumor growth of esophageal carcinomas [50].

$\mathrm{Li}$ EM et al studied the role of NGAL in invasion, division and proliferation of an esophageal carcinoma cell line. Their results demonstrated that the antisense blocking of NGAL transcription not only decreased effectively the activity of MMP-9 and MMP-2 secreted by SHEEC cells, but also suppressed significantly the invasion of these cells in nude mice. However, it was shown that NGAL was not apparently related with division and proliferation of SHEEC tumor cells [51]. Furthermore, the same authors, in attempt to demonstrate the regulation mechanism of NGAL overexpression in SHEEC, analyzed the structural characters of $5^{\prime}$-untranslated region( $5^{\prime}$-UTR) and 3'untranslated region (3'-UTR) of NGAL. Upon cloning and DNA sequencing of 69 bp 5'-UTR and $147 \mathrm{bp} \mathrm{3'-}$ UTR of NGAL gene they did not observe any base pair mutations [52].

\section{Gastric cancer}

Gastric cancer (GC) is the final result of a multistep process initiated by environmental factors, including diet and Helicobacter pylori infection [53]. H. pylori infection is one of the most important risk factors for this malignancy $[54,55]$.

During infection, H. pylori synthesize siderophores, which chelate $\mathrm{Fe}^{3+}$ with high affinity and facilitate its transport into the pathogen [56-58]. The host cells respond to infection by increasing the secretion of NGAL that binds the bacterial siderophores and prevents their uptake into bacteria. The iron depletion results in inhibiting $H$. pylori growth [59].

NGAL and NGAL/MMP9 complex were shown to be upregulated in GC tissue (mainly in neutrophils and epithelial cells) compared to adjacent normal gastric mucosa, confirming the hypothesis that the association of NGAL with MMP9 could prevent extracellular autodegradation of the proteinase. Enhanced levels of the NGAL/MMP9 complex, but not of MMP-9 and lipocalin-2, have been related to worse clinical outcome in cancer patients and significantly associated with the classifications of Lauren and WHO, suggesting that NGAL/MMP9 complex could be considered as a novel prognostic factor for gastric cancer [13].

Wang HJ et al [60] proposed NGAL as a potential biomarker for prognosis and an ancillary diagnostic test of gastric cancer. In this study, they showed high levels of NGAL expression in 333 GC patients by immunohistochemistry. NGAL was correlated with size of tumor, Lauren's classification, lymph node metastasis, vascular invasion, distant metastasis and TNM stage. The multivariate analysis indicated that NGAL can be used as an independent prognostic factor. Serum NGAL levels were determined in blood samples from 63 healthy donors and $60 \mathrm{GC}$ patients and analysed according to TNM. NGAL blood levels were higher than those of CA19-9 in TNM I patients, and higher than those of CEA and CA199 in TNM II. Therefore, serum NGAL has a great potential as a tumor marker for GC and could be associated with a poor prognosis [60].

According to the exclusion criteria designed for the purpose of our present study, no data on GC were generated by our analyses.

\section{Head and neck}

Our "in silico" analysis showed a significant downregulation of NGAL in head and neck cancer compared to the normal counterpart. In fact, $94.6 \%$ of head and neck cancer displayed NGAL transcripts below the $25^{\text {th }}$ percentile of "normal" values, while no samples showed mRNA levels of NGAL above the $75^{\text {th }}$ percentile. However, our IHC evaluation is in line with previous data [61] as expression of NGAL appeared to be moderate in $50 \%$ of cases and absent in normal tissue.

\section{Hepatocellular Carcinoma (HCC)}

Zhang $\mathrm{Y}$ et al demonstrated the up-regulation of NGAL expression in HCC was significantly correlated with unfavourable clinic-pathologic features and 
independent poor prognostic factor for overall survival in patients [62]. In agreement, our analysis showed a significant up-regulation of NGAL mRNA levels in HCC from 2.3- to 8.6-fold changes in comparison to normal hepatic tissues in the three datasets analyzed. Similar data were obtained by IHC considerations.

\section{Lung cancer}

At the present, few studies have been performed to evaluate the role of NGAL in lung cancer. However, Friedl A et al found high NGAL levels in lung adenocarcinoma [20]. Accordingly, in the present study we detected a constant NGAL upregulation both at $\mathrm{mRNA}$ and protein levels for adenocarcinoma histotype. In contrast, NGAL was not overexpressed in carcinoid lung cancer.

\section{Melanoma}

In melanoma a substantial down-regulation of NGAL was observed only in metastatic disease versus primary tumor while no statistic differences were observed in NGAL mRNA levels between primary tumor and normal tissue. Protein expression of NGAL was not detected by IHC (Human Protein Atlas web site) (Figure 4, Panel K). To our knowledge no previous data were generated on NGAL in melanoma tissue samples.

\section{Ovarian cancer}

Epithelial ovarian cancer is one of the most aggressive cancers diagnosed in women with high mortality rate. This cancer is usually asymptomatic and often diagnosed late in the disease process [63]. Unfortunately, there are no specific markers for early diagnosis. Lim R et al analysed NGAL by IHC in a total of 59 ovarian tissues including normal, benign, borderline and malignant (grades 1, 2 and 3). NGAL expression was weak or moderate in benign tissues. Both borderline and grade 1 tumors displayed the highest amount of NGAL expression with moderate to strong staining, whereas in grade 2 and 3 tumors, the extent of staining was significantly less $(\mathrm{p}<0.01)$ and staining intensity was weak to moderate. Additionally, the authors analyzed, by ELISA, NGAL levels in 62 serum samples from normal individuals and ovarian cancer patients (grade 1). The NGAL concentration was 2 and 2.6-fold higher in patients with benign tumors and cancer patients (grade 1) [19]. In line with results provided by Lim et al, all datasets here examined showed an upregulation of NGAL in ovarian cancer samples, with a range from 3 to 6 fold. Furthermore, the analysis of both Bittner and Anglesio datasets (Ref. in Table 2) revealed a significant reduction of NGAL mRNA levels in metastatic disease (see Table
2). In the same study, Lim and collaborators analyzed NGAL in ovarian cancer cell lines treated with epidermal growth factor (EGF) indicating that NGAL expression was downregulated in ovarian cancer cell lines undergoing the epithelial to mesenchymal transition (EMT) induced by EGF. Downregulation of NGAL expression correlated with the upregulation of vimentin, enhanced cell dispersion and downregulation of E-cadherin expression, some of the hallmarks of EMT. These data indicate that NGAL may be a good marker to monitor transformation of benign lesions to premalignant and malignant ovarian tumors and that the molecule may be involved in the progression of epithelial ovarian malignancies [19].

NGAL, as well as other proteins, was shown to be regulated in ovarian cancer cell lines by 17 beta-estradiolestrogen [64]. More recently Cho et al. described the upregulation of NGAL in a panel of 54 ovarian cancers, 15 borderline and 53 benign ovarian tumors, and 90 healthy controls by real time PCR and immunohystochemical analysis. NGAL levels were significantly higher in ovarian tissues and particularly in well-differentiated tumors. Similar results were obtained by analyzing NGAL serum levels from ovarian cancer patients showing highest levels in differentiated cancer [65]. Notably, according to previous data, the results of the present study show that $91,2 \%$ of ovarian cases displayed NGAL transcripts above the $75^{\text {th }}$ percentile of the "normal" values, while $0.4 \%$ below the $25^{\text {th }}$ percentile. Similar trend was obtained for the IHC analyses. While transcript levels of NGAL were significantly lower in metastatic setting compared to primary tumor.

\section{Pancreatic cancer}

Pancreatic cancer $(\mathrm{PaCa})$ is the fifth leading cause of cancer death in both men and women [66]. Early detection of this disease is not possible in spite of significant diagnostic tools. The effective therapy, surgery, is limited to about $25 \%$ of the cases and often is unable to prevent cancer recurrence in these patients [67]. Much remains to be understood about the natural course and biology of this disease.

Using microarray analysis, many laboratories have reported the differential expression of several novel genes, including that of NGAL, associated with the progression of pancreatic cancer [68-70]. Moniaux et al detected NGAL levels by immunohistochemistry on tissue samples from normal patients, pancreatitis, and pancreatic adenocarcinoma patients. Their results revealed higher levels in pancreatic adenocarcinoma than in normal and pancreatitis samples [71]. These findings are in agreement with the results of the present study in which we observe a constant upregulation of NGAL at both mRNA and protein expression levels in pancreatic adenocarcinoma samples vs normal tissues. Moniaux et al also evaluated NGAL levels in pancreatic cancer cell lines with varying grades 
of differentiation documenting a positivity for NGAL expression in both well and moderately differentiated cells. In contrast, NGAL expression was uniformly negative in poorly differentiated adenocarcinoma. Further, they examined NGAL levels in serum samples. They used ELISA to detect NGAL. The authors concluded that NGAL was fairly accurate in distinguishing between pancreatic cancers and non-cancer cases. In conclusion, NGAL is highly expressed in early pancreatic dysplastic lesions, suggesting a possible role as an early diagnostic marker for pancreatic cancer [71].

NGAL is also detected in bile and may be useful as a novel biomarker to distinguish benign from malignant biliary obstruction [72].

The biological roles of NGAL in pancreatic adenocarcinoma have been studied both in vitro and in vivo by Tong et al [17]. The authors transfected $\mathrm{PaCa}$ cells with NGAL and demonstrated no effects on cell viability or sensitivity to chemotherapy, but decreases in cell adhesion, invasion and angiogenesis was observed both in vitro and in vivo. The negative effects on tumor progression and metastasis were due to alteration of FAK phosphorylation and decrease of VEGF production [17]. We can gather from this study that modulation of NGAL activity could control $\mathrm{PaCa}$ angiogenesis and metastasis.

\section{Prostate cancer}

According to the exclusion criteria designed for the purpose of our present study, no differences were identified between prostate cancer tissue and the normal counterparts. Similarly, IHC evaluation did not display any differences between normal and tumor. While, significant differences were observed in metastatic disease of prostate cancer when compared with primary tumors as NGAL transcripts were lower in metastatic setting compared to primary tumor. However, in vitro studies showed that NGAL plays a significant role in the progression of prostate cancer by regulating MMP2 and MMP-9 [73]. Therefore further studies are needed to better clarify the role of NGAL in prostate cancer, as until now conflicting results have been generated between "in silico" and "in vitro" data.

\section{Renal tumor}

The incidence of renal cell carcinoma (RCC) is growing [74]. Most of the patients initially diagnosed with localized disease are cured by surgery, but over $30 \%$ of them die from relapse. The molecular basis of a great diversity in clinical behavior of RCC is still unclear and makes it a target to investigate the nature of these heterogeneities [75].

A recent immunohistochemical study on a set of 30 surgically-resected renal tumors revealed that NGAL is expressed in several histotypes of renal tumors especially in papillary and chromphobe histotypes. NGAL expression is highest in the higher histological grade of papillary and clear cell RCC and in its peritoneal metastasis [76]. The authors suggested that the upregualtion of NGAL in the above-mentioned tumor histotypes could be related to an increased requirement of iron uptake and could justify the use of iron chelators for renal cancer therapies. In agreement, our analysis revealed an upregulation of NGAL in RCC. Conversely, IHC evaluation did not show any immunostaining for NGAL. It was further shown that NGAL, as detected by ELISA, had predict value for progression free survival in RCC patients treated with sunitinib malate [77]. While, most recent data conducted by Di Carlo does not reach any conclusive results on the usefulness of NGAL as a diagnostic marker [78].

\section{Thyroid cancer}

Our data show that transcript levels of NGAL are higher in tumor thyroid cancer (papillary carcinoma) when compared with normal counterpart. In fact, $83.7 \%$ of case displayed NGAL transcripts above the $75^{\text {th }}$ percentile of "normal" values, while $6.1 \%$ of cases showed mRNA levels of NGAL below the $25^{\text {th }}$ percentile (Figure 3, Panel $\mathrm{K})$. In contrast, no protein expression was detect by IHC (Human Protein Atlas web site). According to mRNA expression data, previous studies showed that NGAL is overexpressed in thyroid cancer [79-81].

\section{Hematological malignancies}

Different then for solid tumor, NGAL expression in hematological malignancies displays a very homogeneous behavior: in fact, all the datasets that reach the levels of significance $\mathrm{p}<0.01$ exhibit an uniform downregulation of NGAL compared to controls. Datasets analyzed included myeloma and leukemias (ALL, acute lymphoblastic leukemia; AML, acute myeloid leukemia, CLL; chronic lymphocytic leukemia). Accordingly, recent data show that highest mRNA NGAL levels were associated with better prognosis in AML [82]. According to the exclusion criteria designed for the purpose of the present study, no data on chronic myeloid leukemia (CML) were generated by computational analysis. However, NGAL was identified in an expression profiling study on CML cells. In this work, the authors analysed gene expression profiles of cancer cells from 27 patients using a cDNA microarray. Among the 150 genes up-regulated, they observed an increase of NGAL mRNA levels in CML patients [83]. Subsequently, Villalva $\mathrm{C}$ et al have performed RT-PCR for NGAL expression in a large cohort of CML patients. Their results indicate that NGAL is expressed in parallel with the BCR-ABL oncoprotein at the early stage of leukemia process and it is secreted at high levels in these 
patients. The authors have excluded the possibility that the large increase of NGAL expression in CML patients at diagnosis resulted from the presence of circulating myelocytes in blood, which constitutively secrete NGAL protein during maturation [84]. Leng et al have proposed two activities associated with NGAL in a mouse model of CML tumorigenesis. On the one hand, NGAL induces apoptosis of normal hematopoietic cells resulting in the replacement of these with leukemic cells and on the other NGAL facilitates tissue invasion through stabilization of MMP-9 activity [85].

\section{CONCLUSION}

Our computational analysis suggest an active role of NGAL in early stages of tumor development, reason that many authors proposed NGAL as a diagnostic and prognostic marker. While a decrease of NGAL expression in metastatic samples was detected when compared to matched primary tumors. This observation suggests a common inactivation pathway of NGAL gene during distant tumor dissemination and leads us to venture the hypothesis that NGAL could play a protective role in metastatic development.

In particular, the tumors showing higher NGAL expression (expression levels greater than the $75^{\text {th }}$ percentile of "normal" samples) were: ovarian (91.2\%), thyroid $(83.7 \%)$, liver $(68.8 \%)$, colon $(66.3 \%)$, kidney $(64.7 \%)$, lung $(63.1 \%)$, pancreas $(60.2 \%)$ and bladder $(50.5 \%)$. While, the percentages of tumor cases showing NGAL transcripts below the $25^{\text {th }}$ percentile of "normal" values were almost $100 \%$ of all hematological malignancies and $94.6 \%$ of head and neck cancer, $71.4 \%$ of esophagus cancer and $59.4 \%$ of cervical carcinoma. These data suggest that NGAL is a candidate marker for tumor growth in a fraction of solid tumor and a favorable prognostic factor for the remaining cancer types showing lower levels of NGAL transcript levels.

The analysis of previous studies revealed a lack of information about NGAL correlation with metastasis and almost completely consistent with the bionformatic data. The present study deepens the knowledge of the molecular mechanisms sustaining NGAL expression in tumor cells and its effects on cancer metastatic behavior. Further investigations are required to elucidate the function of NGAL in tumor development and metastatic processes.

\section{MATERIAL AND METHODS}

ONCOMINE software (https://www.oncomine.com) was used (December 2013) to compare mRNA expression levels between normal tissue versus tumor and primary tumor versus metastatic, and in both cases evaluated on biopsy samples. Statistical analysis of the differences in NGAL mRNA expression between the abovementioned sets of samples was accomplished through use of
ONCOMINE algorithms. Only datasets generated by Affymetrix U133 platform were considered for the present analysis. Of note, this platform used the "212531_at" NGAL probe set. Datasets showing different expression analysis between normal and tumor tissues with statistical significance less than 0.01 (by t-test) and fold change $\leq-2$ or $\geq 2$ were included; while, those showing a differential expression between primary tumor and metastasis with a statistic significance less than 0.05 (by t-test) and fold change $\leq-1.5$ or $\geq 1.5$ were considered. According to these criteria, 38 datasets were used for the purpose of the study. Of these, 29 were used for the comparative analysis between normal and tumor tissues [86-111]; while, 9 were used to analyze the differences between primary tumor and metastasis [112-118]. Fold change was calculated to evaluate the changes in gene expression between the groups of samples included in this analysis. Properties of the datasets are presented in Tables 1 and 2 .

To assess the distribution of NGAL transcript levels among cancer types and normal samples, mRNA expression levels from Oncomine analysis were normalized using an housekeeping gene in each dataset and then merged together. The choice of the housekeeping gene was made on the basis of the homogenous mRNA levels distribution. When more than one probset was available, the mean value of the same housekeeping gene was used for the normalization. To define the "normal range" of expression we calculated the 25 th and the 75 th percentile of NGAL transcript levels in normal samples for each tumor type. Accordingly, the percentage of tumor samples showing NGAL levels outside the defined "normal range" was calculated.

NGAL protein expression was performed by analyzing the web site of Human Protein Atlas (http:// www.proteinatlas.org/). As indicate in the web site, expression of NGAL for each tumor type was evaluated as strong, moderate, weak and negative immunostaining. The Sigma-Aldrich HPA002695 NGAL antibody was employed for this analysis.

\section{ACKNOWLEDGMENTS:}

This work was in part supported by: the Italian League Against Cancer (ML), the Fondazione Veronesi (JP, SC) and the Italian Ministry of Health, Ricerca Finalizzata Stemness 2008 (ML, RM).

\section{REFERENCES}

1. Flower DR. The lipocalin protein family: structure and function. Biochem J. 1996; 318: 1-14.

2. Kjeldsen L, Johnsen A., Sengeløv H, Borregaard N. Isolation and primary structure of NGAL, a novel protein associated with human neutrophil gelatinase. J Biol Chem. 1993; 268: 10425-10432. 
3. Goetz DH, Holmes MA, Borregaard N, Bluhm ME, Raymond KN, Strong RK. The neutrophil lipocalin NGAL is a bacteriostatic agent that interferes with siderophoremediated iron acquisition. Mol Cell- 2002; 10:1033-43.

4. Yang J, Goetz D, Li JY, Wang W, Mori K, Setlik D, Du T, Erdjument-Bromage H, Tempst P, Strong R, Barasch J. An iron delivery pathway mediated by a lipocalin. Mol Cell. 2002; 10: 1045-56.

5. Devireddy LR, Gazin C, Zhu X, Green MR. A cell-surface receptor for lipocalin $24 \mathrm{p} 3$ selectively mediates apoptosis and iron uptake. Cell. 2005; 123: 1293-305.

6. Bolignano D, Donato V, Coppolino G, Campo S, Buemi A, Lacquaniti A, Buemi M. Neutrophil gelatinase-associated lipocalin (NGAL) as a marker of kidney damage. Am J Kidney Dis. 2008; 52: 595-605.

7. Cowland JB, Sørensen OE, Sehested M, Borregaard N. Neutrophil gelatinase-associated lipocalin is up-regulated in human epithelial cells by IL-1 beta, but not by TNF-alpha. J Immunol. 2003; 171: 6630-9.

8. Cowland JB, Muta T, Borregaard N. IL-1beta-specific upregulation of neutrophil gelatinase-associated lipocalin is controlled by IkappaB-zeta. J Immunol. 2006; 176: 555966.

9. Karlsen JR, Borregaard N, Cowland JB. Induction of neutrophil gelatinase-associated lipocalin expression by costimulation with interleukin-17 and tumor necrosis factoralpha is controlled by IkappaB-zeta but neither by C/EBPbeta nor C/EBP-delta. J Biol Chem. 2010; 285: 14088-100.

10. Li SH, Hawthorne VS, Neal CL, Sanghera S, Xu J, Yang J, Guo H, Steeg PS, Yu D. Upregulation of neutrophil gelatinase-associated lipocalin by ErbB2 through nuclear factor-kappaB activation. Cancer Res. 2009; 69: 9163-8.

11. Yan L, Borregaard N, Kjeldsen L, Moses MA. The high molecular weight urinary matrix metalloproteinase (MMP) activity is a complex of gelatinase B/MMP-9 and neutrophil gelatinase-associated lipocalin (NGAL). Modulation of MMP-9 activity by NGAL. J Biol Chem. 2001; 276: 3725865.

12. Fernández CA, Yan L, Louis G, Yang J, Kutok JL, Moses MA. The matrix metalloproteinase-9/neutrophil gelatinaseassociated lipocalin complex plays a role in breast tumor growth and is present in the urine of breast cancer patients. Clin Cancer Res. 2005; 11: 5390-5.

13. Kubben FJ, Sier CF, Hawinkels LJ, Tschesche H, van Duijn W, Zuidwijk K, van der Reijden JJ, Hanemaaijer R, Griffioen G, Lamers CB, Verspaget HW. Clinical evidence for a protective role of lipocalin-2 against MMP9 autodegradation and the impact for gastric cancer. Eur $\mathbf{J}$ Cancer. 2007; 43: 1869-76.

14. Zhang H, Xu L, Xiao D, Xie J, Zeng H, Wang Z, Zhang X, Niu Y, Shen Z, Shen J, Wu X, Li E. Upregulation of neutrophil gelatinase-associated lipocalin in oesophageal squamous cell carcinoma: significant correlation with cell differentiation and tumour invasion. J Clin Pathol. 2007; 60:
$555-61$.

15. Smith ER, Zurakowski D, Saad A, Scott RM, Moses MA. Urinary biomarkers predict brain tumor presence and response to therapy. Clin Cancer Res 2008; 14:2378-86.

16. Venkatesha S, Hanai J, Seth P, Karumanchi SA, Sukhatme VP. Lipocalin 2 antagonizes the proangiogenic action of ras in transformed cells. Mol Cancer Res. 2006; 4: 821-829.

17. Tong Z, Kunnumakkara AB, Wang $\mathrm{H}$, Matsuo $\mathrm{Y}$, Diagaradjane P, Harikumar KB, Ramachandran V, Sung B, Chakraborty A, Bresalier RS, Logsdon C, Aggarwal BB, Krishnan S, et al. Neutrophil gelatinase-associated lipocalin: a novel suppressor of invasion and angiogenesis in pancreatic cancer. Cancer Res. 2008; 68: 6100-8.

18. Lee HJ, Lee EK, Lee KJ, Hong SW, Yoon Y, Kim JS. Ectopic expression of neutrophil gelatinase-associated lipocalin suppresses the invasion and liver metastasis of colon cancer cells. Int J Cancer. 2006; 118: 2490-7.

19. Lim R, Ahmed N, Borregaard N, Riley C, Wafai R, Thompson EW, Quinn MA, Rice GE. Neutrophil gelatinase-associated lipocalin (NGAL) an early-screening biomarker for ovarian cancer: NGAL is associated with epidermal growth factor-induced epithelio-mesenchymal transition. Int J Cancer. 2007; 120: 2426-34.

20. Friedl A, Stoesz SP, Buckley P, Gould MN. Neutrophil gelatinase-associated lipocalin in normal and neoplastic human tissues. Cell type-specific pattern of expression. Histochem J. 1999; 31: 433-41.

21. Yang J, Moses MA. Lipocalin 2: a multifaceted modulator of human cancer. Cell Cycle. 2009; 8: 2347-52.

22. Bolignano D, Donato V, Lacquaniti A, Fazio MR, Bono C, Coppolino G, Buemi M. Neutrophil gelatinase-associated lipocalin (NGAL) in human neoplasias: a new protein enters the scene. Cancer Lett. 2010; 288: 10-6.

23. Chakraborty S, Kaur S, Guha S, Batra SK. The multifaceted roles of neutrophil gelatinase associated lipocalin (NGAL) in inflammation and cancer. Biochim Biophys Acta. 2012; 1826: 129-69.

24. Roy R, Louis G, Loughlin KR, Wiederschain D, Kilroy SM, Lamb CC, Zurakowski D, Moses MA. Tumorspecific urinary matrix metalloproteinase fingerprinting: identification of high molecular weight urinary matrix metalloproteinase species. Clin Cancer Res. 2008; 14: 6610-7.

25. Monier F, Surla A, Guillot M, Morel F. Gelatinase isoforms in urine from bladder cancer patients. Clin Chim Acta. 2000; 299: 11-23

26. Monier F, Mollier S, Guillot M, Rambeaud JJ, Morel F, Zaoui P. Urinary release of 72 and $92 \mathrm{kDa}$ gelatinases, TIMPs, N-GAL and conventional prognostic factors in urothelial carcinomas. Eur Urol. 2002; 42: 356-63.

27. Liu MF, Jin T, Shen JH, Shen ZY, Zheng ZC, Zhang ZL, Xu LY, Li EM, Xu HX. NGAL and NGALR are frequently overexpressed in human gliomas and are associated with clinical prognosis. J Neurooncol. 2011; 104: 119-27. 
28. Barresi V, Tuccari G, Barresi G. NGAL immunohistochemical expression in brain primary and metastatic tumors. Clin Neuropathol 2010; 29: 317-22.

29. Stoesz SP, Friedl A, Haag JD, Lindstrom MJ, Clark GM, Gould MN. Heterogeneous expression of the lipocalin NGAL in primary breast cancers. Int J Cancer. 1998; 79: 565-72.

30. Bauer M, Eickhoff JC, Gould MN, Mundhenke C, Maass N, Friedl A. Neutrophil gelatinase-associated lipocalin (NGAL) is a predictor of poor prognosis in human primary breast cancer. Breast Cancer Res Treat. 2008; 108: 389-97.

31. Shen ZZ, Zhao W, Gu J, Zhang ZQ, Yan L. Expression of matrix metalloproteinase-9 and its complex in the urine of breast cancer patients. Zhonghua Wai Ke Za Zhi. 2003; 41: 817-9.

32. Provatopoulou X, Gounaris A, Kalogera E, Zagouri F, Flessas I, Goussetis E, Nonni A, Papassotiriou I, Zografos G. Circulating levels of matrix metalloproteinase-9 (MMP9), neutrophil gelatinase-associated lipocalin (NGAL) and their complex MMP-9/NGAL in breast cancer disease. BMC Cancer. 2009; 9: 390.

33. Berger T, Cheung CC, Elia AJ, Mak TW. Disruption of the Lcn2 gene in mice suppresses primary mammary tumor formation but does not decrease lung metastasis. Proc Natl Acad Sci U S A. 2010; 107: 2995-3000.

34. Leng $X$, Ding $T$, Lin H, Wang Y, Hu L, Hu J, Feig B, Zhang W, Pusztai L, Symmans WF, Wu Y, Arlinghaus RB. Inhibition of lipocalin 2 impairs breast tumorigenesis and metastasis. Cancer Res. 2009; 69: 8579-84.

35. Shi H, Gu Y, Yang J, Xu L, Mi W, Yu W. Lipocalin 2 promotes lung metastasis of murine breast cancer cells. J Exp Clin Cancer Res. 2008; 27: 83.

36. Chappell WH, Abrams SL, Montalto G, Cervello M, Martelli AM, Candido S, Libra M, Polesel J, Talamini R, Arlinghaus R, Steelman LS, McCubrey JA. Effects of ectopic expression of NGAL on doxorubicin sensitivity. Oncotarget. 2012; 3: 1236-45.

37. Chappell WH, Abrams SL, Franklin RA, LaHair MM, Montalto G, Cervello M, Martelli AM, Nicoletti F, Candido S, Libra M, Polesel J, Talamini R, Milella M, et al. Ectopic NGAL expression can alter sensitivity of breast cancer cells to EGFR, Bcl-2, CaM-K inhibitors and the plant natural product berberine. Cell Cycle. 2012; 11: 4447-61.

38. Wenners AS, Mehta K, Loibl S, Park H, Mueller B, Arnold N, Hamann S, Weimer J, Ataseven B, Darb-Esfahani S, Schem C, Mundhenke C, Khandan F, et al. Neutrophil gelatinase-associated lipocalin (NGAL) predicts response to neoadjuvant chemotherapy and clinical outcome in primary human breast cancer. PLoS One. 2012; 7: e45826.

39. Syrjänen S, Naud P, Sarian L, Derchain S, Roteli-Martins C, Tatti S, Branca M, Erzen M, Hammes LS, Costa S, Longatto-Filho A, Syrjänen K. Up-regulation of lipocalin 2 is associated with high-risk human papillomavirus and grade of cervical lesion at baseline but does not predict outcomes of infections or incident cervical intraepithelial neoplasia. Am J Clin Pathol. 2010; 134: 50-9.

40. Nielsen BS, Borregaard N, Bundgaard JR, Timshel S, Sehested M, Kjeldsen L. Induction of NGAL synthesis in epithelial cells of human colorectal neoplasia and inflammatory bowel diseases. Gut 1996; 38: 414-20.

41. Hu L, Hittelman W, Lu T, Ji P, Arlinghaus R, Shmulevich I, Hamilton SR, Zhang W. NGAL decreases E-cadherinmediated cell-cell adhesion and increases cell motility and invasion through Rac1 in colon carcinoma cells. Lab Invest. 2009;89: 531-48.

42. Bousserouel S, Kauntz H, Gossé F, Bouhadjar M, Soler L, Marescaux J, Raul F. Identification of gene expression profiles correlated to tumor progression in a preclinical model of colon carcinogenesis. Int J Oncol 2010; 36: 148590.

43. Catalán V, Gómez-Ambrosi J, Rodríguez A, Ramírez B, Silva C, Rotellar F, Hernández-Lizoain JL, Baixauli J, Valentí V, Pardo F, Salvador J, Frühbeck G. Up-regulation of the novel proinflammatory adipokines lipocalin-2, chitinase-3 like-1 and osteopontin as well as angiogenicrelated factors in visceral adipose tissue of patients with colon cancer. J Nutr Biochem. 2011; 22: 634-41.

44. Martí J, Fuster J, Hotter G, Solà AM, Deulofeu R, Modolo MM, Loera MA, Ferrer J, Fondevila C, García-Valdecasas JC. Serum neutrophil gelatinase-associated lipocalin in patients with colorectal liver metastases: preliminary results of an exploratory prospective study. Int J Biol Markers. 2010; 25: 21-6.

45. Martí J, Fuster J, Solà AM, Hotter G, Molina R, Pelegrina A, Ferrer J, Deulofeu R, Fondevila C, García-Valdecasas JC. Prognostic value of serum neutrophil gelatinaseassociated lipocalin in metastatic and nonmetastatic colorectal cancer. World J Surg. 2013; 37: 1103-9.

46. Fung KY, Priebe I, Purins L, Tabor B, Brierley GV, Lockett T, Nice E, Gibbs P, Tie J, McMurrick P, Moore J, Ruszkiewicz A, Burgess A, Cosgrove LJ. Performance of serum lipocalin 2 as a diagnostic marker for colorectal cancer. Cancer Biomark. 2013; 13: 75-9.

47. McLean MH, Thomson AJ, Murray GI, Fyfe N, Hold GL, El-Omar EM. Expression of neutrophil gelatinaseassociated lipocalin in colorectal neoplastic progression: a marker of malignant potential? Br J Cancer. 2013; 108: 2537-41.

48. Koshy M, Esiashvilli N, Landry JC, Thomas CR Jr, Matthews RH. Multiple management modalities in esophageal cancer: epidemiology, presentation and progression, work-up, and surgical approaches. Oncologist. 2004; 9: 137-46.

49. Du ZP, Lv Z, Wu BL, Wu ZY, Shen JH, Wu JY, Xu XE, Huang Q, Shen J, Chen HB, Li EM, Xu LY. Neutrophil gelatinase-associated lipocalin and its receptor: independent prognostic factors of oesophageal squamous cell carcinoma. J Clin Pathol. 2011; 64: 69-74. 
50. Fang WK, Xu LY, Lu XF, Liao LD, Cai WJ, Shen ZY, Li EM. A novel alternative spliced variant of neutrophil gelatinase-associated lipocalin receptor in oesophageal carcinoma cells. Biochem J. 2007; 403: 297-303.

51. Li EM, Xu LY, Cai WJ, Xiong HQ, Shen ZY, Zeng Y. Functions of neutrophil gelatinase-associated lipocalin in the esophageal carcinoma cell line SHEEC. Sheng Wu Hua Xue Yu Sheng Wu Wu Li Xue Bao (Shanghai). 2003; 35: 247-54.

52. Li EM, Xu LY, Xiong HQ, Cai WJ, Wu BL, Zhang C, Zhang YF, Lin Y, Shen ZY. Cloning and identification of 5'-untranslated region (UTR) and 3'-untranslated region of neutrophil gelatinase-associated lipocalin (NGAL) gene from esophageal carcinoma cell line SHEEC. Ai Zheng. 2003; 22: 143-7.

53. Stemmermann GN, Fenoglio-Preiser C. Gastric carcinoma distal to the cardia: a review of the epidemiological pathology of the precusors to a preventable cancer. Pathology. 2002; 34: 494-503

54. Uemura N, Okamoto S, Yamamoto S, Matsumura N, Yamaguchi S, Yamakido M, Taniyama K, Sasaki N, Schlemper RJ. Helicobacter pylori infection and the development of gastric cancer. N Engl J Med. 2001; 345: 784-9.

55. Huang JQ, Zheng GF, Sumanac K, Irvine EJ, Hunt RH. Meta-analysis of the relationship between cagA seropositivity and gastric cancer. Gastroenterology. 2003; 125: 1636-1644.

56. Neilands JB. Siderophores: structure and function of microbial iron transport compounds. J Biol Chem. 1995; 270: 26723-26726.

57. Braun V, Braun M. Active transport of iron and siderophore antibiotics. Curr Opin Microbiol. 2002; 5: 194-201.

58. Krewulak KD, Vogel HJ. Structural biology of bacterial iron uptake. Biochim Biophys Acta. 2008; 1778: 17811804.

59. Holmes MA, Paulsene W, Jide X, Ratledge C, Strong RK. Siderocalin (Lcn 2) also binds carboxymycobactins, potentially defending against mycobacterial infections through iron sequestration. Structure. 2005; 13: 29-41.

60. Wang HJ, He XJ, Ma YY, Jiang XT, Xia YJ, Ye ZY, Zhao ZS, Tao HQ. Expressions of neutrophil gelatinaseassociated lipocalin in gastric cancer: a potential biomarker for prognosis and an ancillary diagnostic test. Anat Rec (Hoboken). 2010; 293: 1855-63.

61. Lin CW, Tseng SW, Yang SF, Ko CP, Lin CH, Wei LH, Chien MH, Hsieh YS. Role of lipocalin 2 and its complex with matrix metalloproteinase-9 in oral cancer. Oral Dis. 2012; 18: 734-40.

62. Zhang Y, Fan Y, Mei Z. NGAL and NGALR overexpression in human hepatocellular carcinoma toward a molecular prognostic classification. Cancer Epidemiol. 2012; 36: e294-9.

63. Paley PJ. Ovarian cancer screening: are we making any progress? Curr Opin Oncol. 2001; 13: 399-402.

64. Walker G, MacLeod K, Williams AR, Cameron DA, Smyth JF, Langdon SP. Estrogen-regulated gene expression predicts response to endocrine therapy in patients with ovarian cancer. Gynecol Oncol. 2007; 106: 461-8.

65. Cho H, Kim JH. Lipocalin 2 expressions correlate significantly with tumor differentiation in epithelial ovarian cancer. J Histochem Cytochem. 2009; 57: 513-21.

66. Ahmedin J, Thomas A, Murray T, Thun M. Cancer statistics, 2002. CA Cancer J Clin. 2002; 52: 23-42.

67. Cooperman AM. Pancreatic cancer: the bigger picture. Surg Clin North Am. 2001; 81: 557-74.

68. Argani P, Rosty C, Reiter RE, Wilentz RE, Murugesan SR, Leach SD, Ryu B, Skinner HG, Goggins M, Jaffee EM, Yeo CJ, Cameron JL, Kern SE, et al. Discovery of new markers of cancer through serial analysis of gene expression: prostate stem cell antigen is overexpressed in pancreatic adenocarcinoma. Cancer Res. 2001; 61: 4320-4324

69. Han H, Bearss DJ, Browne LW, Calaluce R, Nagle RB, Von Hoff DD. Identification of differentially expressed genes in pancreatic cancer cells using cDNA microarray. Cancer Res. 2002; 62: 2890-2896.

70. Terris B, Blaveri E, Crnogorac-Jurcevic T, Jones M, Missiaglia E, Ruszniewski P, Sauvanet A, Lemoine NR. Characterization of gene expression profiles in intraductal papillary-mucinous tumors of the pancreas. Am J Pathol. 2002; 160: 1745-1754

71. Moniaux N, Chakraborty S, Yalniz M, Gonzalez J, Shostrom VK, Standop J, Lele SM, Ouellette M, Pour PM, Sasson AR, Brand RE, Hollingsworth MA, Jain M, et al. Early diagnosis of pancreatic cancer: neutrophil gelatinaseassociated lipocalin as a marker of pancreatic intraepithelial neoplasia. Br J Cancer. 2008 May 6; 98: 1540-7.

72. Zabron AA, Horneffer-van der Sluis VM, Wadsworth CA, Laird F, Gierula M, Thillainayagam AV, Vlavianos P, Westaby D, Taylor-Robinson SD, Edwards RJ, Khan SA. Elevated levels of neutrophil gelatinase-associated lipocalin in bile from patients with malignant pancreatobiliary disease. Am J Gastroenterol. 2011; 106: 1711-7.

73. Tung MC, Hsieh SC, Yang SF, Cheng CW, Tsai RT, Wang SC, Huang MH, Hsieh YH. Knockdown of lipocalin-2 suppresses the growth and invasion of prostate cancer cells. Prostate. 2013; 73: 1281-90.

74. Rathmell WK, Godley PA. Recent updates in renal cell carcinoma. Curr Opin Oncol. 2010; 22: 250-256.

75. Banks RE, Tirukonda P, Taylor C, Hornigold N, Astuti D, Cohen D, Maher ER, Stanley AJ, Harnden P, Joyce A, Knowles M, Selby PJ. Genetic and epigenetic analysis of von Hippel-Lindau (VHL) gene alterations and relationship with clinical variables in sporadic renal cancer. Cancer Res. 2006; 66: 2000-11.

76. Barresi V, Ieni A, Bolignano D, Magno C, Buemi M, Barresi G. Neutrophil gelatinase-associated lipocalin immunoexpression in renal tumors: correlation with 
histotype and histological grade. Oncol Rep. 2010; 24: 30510.

77. Porta C, Paglino C, De Amici M, Quaglini S, Sacchi L, Imarisio I, Canipari C. Predictive value of baseline serum vascular endothelial growth factor and neutrophil gelatinase-associated lipocalin in advanced kidney cancer patients receiving sunitinib. Kidney Int. 2010; 77: 809-815.

78. Di Carlo A. Evaluation of neutrophil gelatinase-associated lipocalin (NGAL), matrix metalloproteinase-9 (MMP9) and their complex MMP-9/NGAL in sera and urine of patients with kidney tumors. Oncol Lett. 2013; 5: 1677 1681.

79. Barresi V, Vitarelli E, Reggiani Bonetti L, Tuccari G, Barresi G. Diagnostic value of neutrophil gelatinaseassociated lipocalin (NGAL) immunoexpression in follicular-patterned lesions of the thyroid gland. Virchows Arch. 2012; 460: 319-25.

80. Barresi V, Leni A, Tuccari G, Barresi G. Neutrophil gelatinase-associated lipocalin (NGAL) immunohistochemical expression in follicular cell-derived thyroid tumors: a novel diagnostic tool? Histol Histopathol. 2012; 27: 329-36.

81. Iannetti A, Pacifico F, Acquaviva R, Lavorgna A, Crescenzi E, Vascotto C, Tell G, Salzano AM, Scaloni A, Vuttariello E, Chiappetta G, Formisano S, Leonardi A. The neutrophil gelatinase-associated lipocalin (NGAL), a NF-kappaBregulated gene, is a survival factor for thyroid neoplastic cells. Proc Natl Acad Sci U S A. 2008; 105: 14058-63.

82. Yang WC, Lin PM, Yang MY, Liu YC, Chang CS, Chou WC, Hsu JF, Huang CT, Cho SF, Yu WH, Lin SF. Higher lipocalin 2 expression may represent an independent favorable prognostic factor in cytogenetically normal acute myeloid leukemia. Leuk Lymphoma. 2013; 54: 1614-25.

83. Kaneta Y, Kagami Y, Tsunoda T, Ohno R, Nakamura Y, Katagiri T. Genome-wide analysis of gene-expression profiles in chronic myeloid leukemia cells using a cDNA microarray. Int J Oncol. 2003; 23: 681-691.

84. Villalva C, Sorel N, Bonnet ML, Guilhot J, MayeurRousse C, Guilhot F, Chomel JC, Turhan AG. Neutrophil gelatinase-associated lipocalin expression in chronic myeloid leukemia. Leuk Lymphoma. 2008; 49: 984-8.

85. Leng X, Lin H, Ding T, Wang Y, Wu Y, Klumpp S, Sun T, Zhou Y, Monaco P, Belmont J, Aderem A, Akira S, Strong $\mathrm{R}$, et al. Lipocalin 2 is required for BCR-ABL-induced tumorigenesis. Oncogene. 2008; 27: 6110-9.

86. Sanchez-Carbayo M, Socci ND, Lozano J, Saint F, CordonCardo C. Defining molecular profiles of poor outcome in patients with invasive bladder cancer using oligonucleotide microarrays. J Clin Oncol. 2006; 24: 778-89.

87. Scotto L, Narayan G, Nandula SV, Arias-Pulido H, Subramaniyam S, Schneider A, Kaufmann AM, Wright JD, Pothuri B, Mansukhani M, Murty VV. Identification of copy number gain and overexpressed genes on chromosome arm 20q by an integrative genomic approach in cervical cancer: potential role in progression. Genes Chromosomes Cancer. 2008; 47: 755-65.

88. Kaiser S, Park YK, Franklin JL, Halberg RB, Yu M, Jessen WJ, Freudenberg J, Chen X, Haigis K, Jegga AG, Kong $\mathrm{S}$, Sakthivel B, Xu H, et al. Transcriptional recapitulation and subversion of embryonic colon development by mouse colon tumor models and human colon cancer. Genome Biol. 2007; 8: R131.

89. Skrzypczak M, Goryca K, Rubel T, Paziewska A, Mikula M, Jarosz D, Pachlewski J, Oledzki J, Ostrowski J. Modeling oncogenic signaling in colon tumors by multidirectional analyses of microarray data directed for maximization of analytical reliability. PLoS One. 2010; 5: e13091.

90. Hong Y, Downey T, Eu KW, Koh PK, Cheah PY. A 'metastasis-prone' signature for early-stage mismatchrepair proficient sporadic colorectal cancer patients and its implications for possible therapeutics. Clin Exp Metastasis. 2010; 27: 83-90.

91. Hu N, Clifford RJ, Yang HH, Wang C, Goldstein AM, Ding T, Taylor PR, Lee MP. Genome wide analysis of DNA copy number neutral loss of heterozygosity (CNNLOH) and its relation to gene expression in esophageal squamous cell carcinoma. BMC Genomics. 2010; 11: 576.

92. Su H, Hu N, Yang HH, Wang C, Takikita M, Wang QH, Giffen C, Clifford R, Hewitt SM, Shou JZ, Goldstein AM, Lee MP, Taylor PR. Global gene expression profiling and validation in esophageal squamous cell carcinoma and its association with clinical phenotypes. Clin Cancer Res. 2011; 17: 2955-66.

93. Schlingemann J, Habtemichael N, Ittrich C, Toedt G, Kramer H, Hambek M, Knecht R, Lichter P, Stauber R, Hahn M. Patient-based cross-platform comparison of oligonucleotide microarray expression profiles. Lab Invest. 2005; 85: 1024-39.

94. Sengupta S, den Boon JA, Chen IH, Newton MA, Dahl DB, Chen M, Cheng YJ, Westra WH, Chen CJ, Hildesheim A, Sugden B, Ahlquist P. Genome-wide expression profiling reveals EBV-associated inhibition of MHC class I expression in nasopharyngeal carcinoma. Cancer Res 2006; 66: 7999-8006.

95. Yusenko MV, Kuiper RP, Boethe T, Ljungberg B, van Kessel AG, Kovacs G. High-resolution DNA copy number and gene expression analyses distinguish chromophobe renal cell carcinomas and renal oncocytomas. BMC Cancer. 2009; 9: 152.

96. Wurmbach E, Chen YB, Khitrov G, Zhang W, Roayaie S, Schwartz M, Fiel I, Thung S, Mazzaferro V, Bruix J, Bottinger E, Friedman S, Waxman S, et al. Genomewide molecular profiles of $\mathrm{HCV}$-induced dysplasia and hepatocellular carcinoma. Hepatology. 2007; 45: 938-47.

97. Roessler S, Jia HL, Budhu A, Forgues M, Ye QH, Lee JS, Thorgeirsson SS, Sun Z, Tang ZY, Qin LX, Wang XW. A unique metastasis gene signature enables prediction of tumor relapse in early-stage hepatocellular carcinoma 
patients. Cancer Res. 2010; 70: 10202-12.

98. Su LJ, Chang CW, Wu YC, Chen KC, Lin CJ, Liang SC, Lin $\mathrm{CH}$, Whang-Peng J, Hsu SL, Chen $\mathrm{CH}$, Huang CY. Selection of DDX5 as a novel internal control for Q-RTPCR from microarray data using a block bootstrap resampling scheme. BMC Genomics. 2007; 8: 140.

99. Landi MT, Dracheva T, Rotunno M, Figueroa JD, Liu H, Dasgupta A, Mann FE, Fukuoka J, Hames M, Bergen AW, Murphy SE, Yang P, Pesatori AC, et al. Gene expression signature of cigarette smoking and its role in lung adenocarcinoma development and survival. PLoS. 2008; 3: e1651.

100. Okayama H, Kohno T, Ishii Y, Shimada Y, Shiraishi K, Iwakawa R, Furuta K, Tsuta K, Shibata T, Yamamoto S, Watanabe S, Sakamoto H, Kumamoto K, et al. Identification of genes upregulated in ALK-positive and EGFR/KRAS/ ALK-negative lung adenocarcinomas. Cancer Res. 2012; 72: $100-11$.

101. Bonome T, Levine DA, Shih J, Randonovich M, PiseMasison CA, Bogomolniy F, Ozbun L, Brady J, Barrett JC, Boyd J, Birrer MJ. A gene signature predicting for survival in suboptimally debulked patients with ovarian cancer. Cancer Res. 2008; 68:5478-86.

102. Hendrix ND, Wu R, Kuick R, Schwartz DR, Fearon ER, Cho KR. Fibroblast growth factor 9 has oncogenic activity and is a downstream target of Wnt signaling in ovarian endometrioid adenocarcinomas. Cancer Res. 2006; 66: 1354-62.

103. Pei H, Li L, Fridley BL, Jenkins GD, Kalari KR, Lingle W, Petersen G, Lou Z, Wang L. FKBP51 affects cancer cell response to chemotherapy by negatively regulating Akt. Cancer Cell. 2009; 16: 259-66.

104. Segara D, Biankin AV, Kench JG, Langusch CC, Dawson AC, Skalicky DA, Gotley DC, Coleman MJ, Sutherland RL, Henshall SM. Expression of HOXB2, a retinoic acid signaling target in pancreatic cancer and pancreatic intraepithelial neoplasia. Clin Cancer Res. 2005; 11: 3587 96.

105. Badea L, Herlea V, Dima SO, Dumitrascu T, Popescu I. Combined gene expression analysis of whole-tissue and microdissected pancreatic ductal adenocarcinoma identifies genes specifically overexpressed in tumor epithelia. Hepatogastroenterology 2008; 55:2016-27.

106. He H, Jazdzewski K, Li W, Liyanarachchi S, Nagy R, Volinia S, Calin GA, Liu CG, Franssila K, Suster S, Kloos RT, Croce CM, de la Chapelle A. The role of microRNA genes in papillary thyroid carcinoma. Proc Natl Acad Sci U S A. 2005; 102: 19075-80.

107. Vasko V, Espinosa AV, Scouten W, He H, Auer H, Liyanarachchi S, Larin A, Savchenko V, Francis GL, de la Chapelle A, Saji M, Ringel MD. Gene expression and functional evidence of epithelial-to-mesenchymal transition in papillary thyroid carcinoma invasion. Proc Natl Acad Sci U S A. 2007; 104: 2803-8.
108. Giordano TJ, Au AY, Kuick R, Thomas DG, Rhodes DR, Wilhelm KG Jr, Vinco M, Misek DE, Sanders D, Zhu Z, Ciampi R, Hanash S, Chinnaiyan A, et al. Delineation, functional validation, and bioinformatic evaluation of gene expression in thyroid follicular carcinomas with the PAX8PPARG translocation. Clin Cancer Res. 2006;12: 1983-93.

109. Haferlach T, Kohlmann A, Wieczorek L, Basso G, Kronnie GT, Béné MC, De Vos J, Hernández JM, Hofmann WK, Mills KI, Gilkes A, Chiaretti S, Shurtleff SA, et al. Clinical utility of microarray-based gene expression profiling in the diagnosis and subclassification of leukemia: report from the International Microarray Innovations in Leukemia Study Group. J Clin Oncol 2010; 28: 2529-37.

110. Valk PJ, Verhaak RG, Beijen MA, Erpelinck CA, Barjesteh van Waalwijk van Doorn-Khosrovani S, Boer JM, Beverloo HB, Moorhouse MJ, van der Spek PJ, Löwenberg B, Delwel R. Prognostically useful gene-expression profiles in acute myeloid leukemia. N Engl J Med 2004; 350:1617-28.

111. Agnelli L, Mosca L, Fabris S, Lionetti M, Andronache A, Kwee I, Todoerti K, Verdelli D, Battaglia C, Bertoni F, Deliliers GL, Neri A. A SNP microarray and FISHbased procedure to detect allelic imbalances in multiple myeloma: an integrated genomics approach reveals a wide gene dosage effect. Genes Chromosomes Cancer. 2009; 48: 603-14.

112. Tsuji S, Midorikawa Y, Takahashi T, Yagi K, Takayama T, Yoshida K, Sugiyama Y, Aburatani H. Potential responders to FOLFOX therapy for colorectal cancer by Random Forests analysis. Br J Cancer. 2012;106: 126-32.

113. Jones J, Otu H, Spentzos D, Kolia S, Inan M, Beecken WD, Fellbaum C, Gu X, Joseph M, Pantuck AJ, Jonas D, Libermann TA. Gene signatures of progression and metastasis in renal cell cancer. Clin Cancer Res. 2005; 11 : 5730-9.

114. Riker AI, Enkemann SA, Fodstad O, Liu S, Ren S, Morris C, Xi Y, Howell P, Metge B, Samant RS, Shevde LA, Li W, Eschrich $\mathrm{S}$, et al. The gene expression profiles of primary and metastatic melanoma yields a transition point of tumor progression and metastasis. BMC Med Genomics. 2008; 1: 13.

115. Xu L, Shen SS, Hoshida Y, Subramanian A, Ross K, Brunet JP, Wagner SN, Ramaswamy S, Mesirov JP, Hynes RO. Gene expression changes in an animal melanoma model correlate with aggressiveness of human melanoma metastases. Mol Cancer Res. 2008; 6: 760-9.

116. Anglesio MS, Arnold JM, George J, Tinker AV, Tothill R, Waddell N, Simms L, Locandro B, Fereday S, Traficante N, Russell P, Sharma R, Birrer MJ; AOCS Study Group, deFazio A, Chenevix-Trench G, Bowtell DD. Mutation of ERBB2 provides a novel alternative mechanism for the ubiquitous activation of RAS-MAPK in ovarian serous low malignant potential tumors. Mol Cancer Res. 2008; 6: 167890.

117. Vanaja DK, Cheville JC, Iturria SJ, Young CY. Transcriptional silencing of zinc finger protein 185 
identified by expression profiling is associated with prostate cancer progression. Cancer Res 2003; 63: 3877-82.

118. Varambally S, Yu J, Laxman B, Rhodes DR, Mehra R, Tomlins SA, Shah RB, Chandran U, Monzon FA, Becich MJ, Wei JT, Pienta KJ, Ghosh D, et al. Integrative genomic and proteomic analysis of prostate cancer reveals signatures of metastatic progression. Cancer Cell. 2005; 8: 393-406. 